\title{
Bærekraftig afghansk anestesikompetanse
}

\author{
Skader etter skudd, eksplosjoner og trafikkulykker utgjør en betydelig del av det kliniske bildet ved akutt- \\ mottak i Afghanistan. Anestesiologisk kompetanse er spesielt viktig for å begrense morbiditet og mortalitet \\ hos befolkningen i det voldsherjede landet. Norge har gjennom flere år bidratt til å utvikle anestesimiljøet \\ ved det offentlige sykehuset i Mazar-e Sharif gjennom det såkalte Anestesiprosjektet.
}

Jon Magnus Haga

jon.magnus.haga@gmail.com

I tilknytning til mitt politihelsearbeid i Mazar-e Sharif (1) og i nær dialog med Forsvarets sanitet (FSAN) tok jeg høsten 2013 initiativ til å evaluere status ved anestesimiljøet ved Balkh sykehus i Mazar-e Sharif, ett år etter at prosjektet var avsluttet (2).

Evalueringen var basert på samtaler med sentrale aktører i prosjektet, inkludert anestesiolog og afghansk prosjektpartner dr. Hamidullah Seddiqi (3) og Forsvarets overlege $i$ anestesi oberst Knut Ole Sundnes, og besøk ved anestesiavdelingen ved Balkh sykehus i Mazar-e Sharif.

\section{Sivilt-militært anestesisamarbeid}

Anestesiprosjektet var et medisinsk siviltmilitært samarbeidsprosjekt (4) i perioden 2006-12 i den hensikt å bygge bærekraftig anestesikompetanse i Afghanistan. Det var et samarbeid mellom de afghanske helsemyndighetene, Verdens helseorganisasjon (WHO) og det norske forsvar.

Prosjektet ble ledet av Forsvarets overlege i anestesi, oberst Knut Ole Sundnes, og tok utgangspunkt i WHOs retningslinjer for «training program for essential surgical skills in rural hospitals» (5). Parallelt med prosjektet ble relevant medisinsk litteratur oversatt til dari, og det ble organisert for donasjon av norsk anestesimateriell tilpasset Afghanistans ressurssituasjon (personlig meddelelse lege/oberst Sundnes). Anestesiprosjektet ble etablert i provinsene Faryab og Balkh med bakgrunn i den anestesiologiske kompetanse tilknyttet norsk militær tilstedeværelse i områdene, inkludert ved det tidligere norske militære feltsykehuset i Faryab.

Ved oppstart av prosjektet fantes det ingen formell anestesikompetanse i Afghanistan. Det eksisterte heller ingen stillinger eller lønnshjemler for anestesiologer eller spesialsykepleiere i anestesi. Med noen få unntak ble anestesi gitt av teknikere uten helsefaglig bakgrunn. De offentlige sykehusene i Faryab og Balkh betjente hver begge befolkningsgrunnlag på i overkant av én million mennesker. Balkh sykehus hadde i tillegg regionansvar for Nord-Afghanistan, med om lag ni millioner innbyggere.

\section{Voldelig angrep}

Under lege/major Kjetil Ness' ledelse ga prosjektet tidlig svært gode resultater og ble ansett for å være et foregangsprosjekt for helsekompetanseutvikling i Afghanistan

\section{«Anestesien er basert på vestlige retnings- linjer og dokumenteres etter vestlig standard»}

(6). Etter angrep på norsk sanitetspersonell tilknyttet prosjektet i Faryab i mai 2007 (2) og en forverret sikkerhetssituasjon i området ble det ikke mulig å videreføre prosjektet der.

Afghanistans første anestesilege
Anestesiprosjektet ble, til tross for mot-
gangen i Faryab, vellykket videreført ved
Balkh sykehus frem til prosjektet ble avslut-
tet sommeren 2012, i henhold til planen.
Dr. Hamidullah Seddiqi kunne etter seks
års norskledet anestesiveiledning, inkludert
til sammen ett års hospitering ved Bærum
sykehus, Ullevål universitetssykehus, Syke-
huset i Vestfold, Haukeland universitets-
sykehus og St. Olavs hospital, som første
afghanske lege siden 1970 -årene søke myn-
dighetene i landet om godkjenning som
spesialist i anestesiologi.
Anestesiavdelingen ved Balkh sykehus
besto sommeren 2012 av seks anestesiassi-
stenter i tillegg til dr. Seddiqi. De disponerte
det nødvendige anestesiutstyr for å gjennom-
føre forsvarlig generell anestesi (personlig
meddelelse lege/oberst Sundnes). Sundnes
konkluderte med at målene for prosjektet var
oppnådd og at man hadde etablert et poten-

sielt bærekraftig utgangspunkt for en velfungerende anestesiavdeling ved sykehuset.

\section{Bærekraftig læring}

I kjølvannet av Anestesiprosjektet var det knyttet store forventninger til videre utvikling av anestesimiljøet i Balkh og til hvilken grad kompetansen etablert hos dr. Seddiqi ville kunne danne et faglig utgangspunkt for videre kompetanseutvikling på sykehuset, såkalt bærekraftig læring (7).

Mine undersøkelser ved Balkh sykehus høsten 2013 ga holdepunkter for at det hadde vært en positiv utvikling ved anestesiavdelingen gjennom det siste året med tanke på materiell, rutine og tilgang på medisiner.

Avdelingen er i dag i full drift og har tilstrekkelig erfaring og rutine til å støtte seks parallelle operasjoner med generell anestesi. De har tilgang på nødvendig forbruksmateriell og medisiner. Anestesien er basert på vestlige retningslinjer og dokumenteres etter vestlig standard. Alt norsk utstyr som er blitt gitt til anestesiavdelingen ved Balkh sykehus gjennom Anestesiprosjektet, inkludert seks anestesimaskiner, er i bruk og fungerer slik de skal. Det er det siste året utarbeidet skriftlige retningslinjer for vedlikehold av utstyret. Det angis at disse blir fulgt.

Dr. Seddiqi har dessuten klart å skaffe ytterligere nødvendig anestesiutstyr til avdelingen gjennom sykehusets eget logistikksystem og ekstern finansiering. Anestesimiljøet fremstår dermed på mange områder som mer robust i dag enn da prosjektet ble avsluttet for litt over ett år siden.

Personellsituasjonen ved avdelingen er derimot stadig vanskelig. Flere oppgaver uten tilsvarende økning $\mathrm{i}$ bemanning har ført til et stort arbeidspress. Dr. Seddiqi har derfor utarbeidet en plan for utdanningsstillinger $i$ anestesi ved avdelingen og venter for tiden på svar fra myndighetene om tildeling av nødvendige stillingshjemler.

Anestesiprosjektet har, slik jeg ser det, hatt en avgjørende betydning for dagens anestesimiljø ved Balkh sykehus, og avdelingen synes å ha hatt en positiv utvikling det siste året. Gitt at arbeidet med å etablere 
utdanningsstillinger $\mathrm{i}$ anestesi ved Balkh sykehus lykkes, tyder mye på at Anestesiprosjektet har evnet å etablere bærekraftig afghansk anestesikompetanse i Balkh.

Jeg takker Forsvarets overlege i anestesi oberst Knut Ole Sundnes for nyttige innspill og veiledning i mitt arbeid med Anestesiprosjektet og anestesio$\log$ dr. Hamidullah Seddiqi for verdifulle diskusjoner omkring dagens situasjon i anestesimiljøet i Balkh.

\section{Jon Magnus Haga (f. 1984)}

er stipendiat ved Nasjonalt kunnskapssenter om vold og traumatisk stress (NKVTS). Han har inntil nylig jobbet som lege i Forsvaret og utarbeidet høsten 2013 en strategi for sanitetsutvikling av afghansk politi gjennom Norwegian Police Advisory Team (NOR PAT). Han har fra tidligere erfaring fra internasjonalt helsearbeid gjennom studie- og forskningsopphold i flere land og som praktikant ved Verdens helseorganisasjon (WHO).

Forfatter har fylt ut ICMJE-skjemaet og oppgir ingen interessekonflikter.

\section{Litteratur}

1. Haga JM. Afghanistan - politiopprustning for den avgjørende timen. Tidsskr Nor Legeforen 2014; 134: $1268-70$

2. Ness K. Anestesi og krig i Faryab. Tidsskr Nor Legeforen 2008; 128: 1554-6.

3. Homlong L. Anestesilegen i Mazar-e Sharif. Tidsskr Nor Legeforen 2012; 132: 1186-8.

4. Rosén LS. Militære leger i væpnede konflikter. Tidsskr Nor Legeforen 2008; 128: 1507.

5. Verdens helseorganisasjon. Surgical care in the district hospital. Genève: WHO, 2003.

6. Storvik AG. Lover mer til anestesiprosjekt. Dagens Medisin 2007; nr. 20. www. dagensmedisin.no/ nyheter/lover-mer-til-anestesiprosjekt/ (12.12.2013).

7. Lillegård T. Bærekraftig læring og varig kompetanseutvikling i internasjonale utdanningsprosjekt. Masteroppgave. Oslo: Det utdanningsvitenskapelige fakultet, Universitetet i Oslo, 2013.

Mottatt 24.2. 2014 og godkjent 27.4. 2014. Redaktør: Siri Lunde Strømme. 